\title{
Landlord Villages of Iran as Examples of Political Economy and Materiality
}

Ruth Young and Hassan Fazeli

School of Archaeology and Ancient History, University of Leicester, UK

Department of Archaeology, University of Tehran, Iran

Landlord villages

6981

18 November 2016

Ruth Young, School of Archaeology \& Ancient History, University of Leicester, LE1 7RH rly3@le.ac.uk 


\section{Landlord Villages of Iran as Examples of Political Economy and Materiality}

Ruth Young and Hassan Fazeli

Summary

This paper uses a political economy framework to explore the role of external agents of change in Iran, and the impact of foreign trade during the 19th and 20th centuries, particularly with Russia and Britain. The results of an historical archaeology exploring landlord villages in the Tehran Plain are analysed here to show how the extremely long-lived landlord village form of land tenure and economic and social control offers a useful case study through which to approach an understanding of the impact of the political economy on rural populations of the period. 


\section{INTRODUCTION}

Historical archaeology is very new to Iran and offers a highly relevant way of exploring a recent past that both incorporates and transcends other more traditional ways of understanding the last few centuries. Historians necessarily draw on documentary evidence as their primary source, which in Iran (as elsewhere) means relying on partial accounts of contemporary or past events in the form of official records, and accounts and descriptions by elites and the winners. This may include proto-historic material in the form of traveller's accounts, foreign newspaper reports or foreign diplomatic records in the absence of direct Iranian accounts and sources. Anthropologists and ethnographers proliferated in Iran between the 1950s and late 1970s, recording aspects of contemporary life (often rural), offering invaluable observations and accounts of everyday life that work as a useful counterpoint to historical accounts. As historical archaeology can draw together historical and ethnographic material and add these to a study of material culture to offer new, alternative ways of learning about the past (particularly quotidian pasts that may be ignored in historical accounts and before or outside ethnographic focus) it is a useful way of learning more about rural Iran of the last few centuries. Through the adoption of a political economy approach, new field data and extant historical accounts can be fully enmeshed in the analysis of social transformations in an everyday rural context, providing new understandings of these changes at many different scales.

The Qajar dynasty that ruled Iran during the 19th century are generally characterised as weak, decentralised, and highly corrupt. Britain and Russia dominated Iranian political and economic activity for much of the 19th and 20th centuries motivated by territorial expansion and trade. Iran was not a capitalist country, in the sense of modern Britain or the USA for example, although it was the setting for numerous and expanding capitalist ventures (both foreign and home-grown) including production of cash crops and large scale import-export 
practices. Iran was linked to an increasingly global economy through the presence of Britain and Russia, and their use of the country as an extension of their own economies, rather than through any concerted efforts of the government itself. Revolutions linked to trade (the Tobacco Revolution of 1891-92) and politics (the Constitutional Revolution of 1906-07) alongside widespread poverty and inept rule laid the foundations for the demise of the Qajars and the rise of the Pahlavi dynasty in the first quarter of the 20th century. While this should have resulted in an era of major change, the same problems for the vast majority of the population continued, and in 1978 the last Shah left Iran, to be swiftly followed by the leadership of Imam Khomeini.

This paper uses a political economy framework to explore the role of external agents of change, and the impact of foreign trade during the 19th and 20th centuries, particularly with Russia and Britain. Between 2007-09 an historical archaeology project exploring landlord villages in the Tehran Plain was directed by the authors, and the results of this project are analysed here to show how this extremely long-lived form of land tenure and economic and social control offers a useful case study through which to approach an understanding of the impact of the political economy on rural populations of the period. Drawing on analyses of material culture and ethnographic interviews allows us to examine changes in consumerism, and consider how globalization and industrialization processes were translated within Iran, a country with a very different form of political economy to other regions in which these processes have been studied

\section{LANDLORD VILLAGES OF IRAN}

Landlord villages were a major feature of rural Iran for many centuries up to the 1960s and 1970s, representing not only the dominant form of land tenure, but also the dominant form of 
socio-economic organization which ensured that wealth and power was concentrated in the hands of a small percentage of the population. ${ }^{1}$ The prevalence of landlord villages meant that the vast majority of the population lived in what many historical accounts describe as great poverty, with all the accompanying social evils. ${ }^{2}$ Wealthy, absentee landlords owned whole villages, which were usually enclosed by high mud brick walls, along with the surrounding agricultural and grazing lands (see Fig. 1). In general, these landlords (arbobs) or their representatives (khatkhodas) decided who would live within their villages and which plots of land they could cultivate. In some villages there was a degree of relative security where houses remained in possession of the same families for generations, but landlords usually ensured that their tenants cultivated different plots of land every few years; this meant that everyone had periodic access to the better plots of land, but also meant that most farmers lacked personal commitment to improving the land. ${ }^{3}$

This system of land ownership by a small number of powerful individuals and their social and economic control of the tenants, primarily farmers and families working the land, is believed to be of great antiquity, probably in place from the early Islamic period (mid-7th century AD) onwards. ${ }^{4}$ Over many centuries Iranian rulers used land to reward and support military and other elites, thus creating a powerful land-owning class. ${ }^{5}$ Although landowning statistics were not recorded, or at least not consistently or accurately, ${ }^{6}$ it has been asserted that 'the outstanding characteristic of village society in the 1950s and early 1960s was its domination by large landowners'. ${ }^{7}$ Ownership of land conferred status and prestige, which was considered to be at least as important as the possible wealth to be gained from working the land.

Landlord villages have been described as feudal in nature, but as Richards ${ }^{8}$ points out, this is in fact inaccurate. While medieval European peasants had a measure of legal security and could pass down certain land access rights from generation to generation, Iranian villagers 
had no similar rights and were subject to what has been called the 'arbitrary will of the landlord' ${ }^{9}$ The landlord - villager relationship was generally highly polarised where:

The landowner regards the peasant virtually as a drudge, whose sole function is to provide him with his profits and who will, if treated with anything but severity, cheat him of his due. ${ }^{10}$

The landowners did not consider the provision of good housing or hygiene facilities important for the residents of their villages. Keddie’s survey work in 1954 agreed, having found 'appalling conditions; locusts and clover as the main food supply in a few areas; a majority seriously diseased'. ${ }^{11}$ Some analysts argue that the extremely arbitrary nature of power wielding affected all members of society, including landowners, acting as a disincentive to invest or change. ${ }^{12}$ It has been argued that capitalist inequalities have their roots in pre-capitalist foundations, and this can be seen in this case study. While the 19th and 20th centuries brought greater contact with capitalism and industrialization, their real impact in Iran was to benefit elites, while conditions for workers remained harsh, even when transformed from agriculture to manufacturing. ${ }^{13}$

In addition to arbabi, or land owned by landlords, there was also khalisah, or land owned by the state and in the public domain. ${ }^{14}$ According to accounts of khalisah villages in Varamin district south of Tehran in the 1870s and 1880s, the buildings were very badly neglected ${ }^{15}$. Lambton notes that in an 1878-79 report on an area near Tehran 'most of the villages of Khwar, whether arbabi or khaliseh, were in a state of decay, and also that arbabi land was everywhere in better condition than khaliseh'. ${ }^{16}$ This is presumably because landlords at least had a vested interest in making a profit from their lands, and thus were prepared to invest in irrigation, equipment and seed as a minimum, whereas state (or crown) land did not need to provide regular returns. 
Agricultural production in Iran was often viewed as the result of five elements: land, labour, water, oxen and seed. ${ }^{17}$ The person who owned and contributed each of the elements was then entitled to claim a proportionate share of the resulting produce; thus if the landlord contributed land, water and seed he claimed three-fifths of the produce at harvest time (and in most cases the landlord was male, although female landlords were not unknown). In practice, the system of taxes and levies forced onto those who actually farmed the land meant that they remained within a cycle of labour and debt which tied them to the land and the landlord, and provided them with a bare subsistence living. ${ }^{18}$ While the landlord needed farmers and their families to be healthy enough to carry out work in the fields, this was balanced against ensuring that these people did not summon enough individual and communal will to attempt to change the system from the bottom up. ${ }^{19}$ Indeed, historical accounts report that any peasants who tried to flee the land during particularly grim periods were often forcibly returned to their villages. ${ }^{20}$

Irrigation is of key importance to agricultural activity in Tehran Plain as in much of Iran, based on the ancient qanat system of channelling groundwater from higher altitudes to lower altitudes. Qanat irrigation systems required a great deal of investment to build and maintain, and it was the responsibility of the landlord (or agent) to ensure that there was sufficient surplus from a village to pay the specialists, and organise village labour to take on the regular non-specialist tasks. Access to water would have been by schedule which would have been organised by the village headman, working under the landlord. It has been argued that investment in agriculture in Iran prior to the 1960s and 1970s was largely confined to maintaining and expanding qanat systems. ${ }^{21}$ In his study of the khalisah, Nezam-Mafi has calculated that in Varamin District in the 1870s only one third of the land was under cultivation, and this was due to restricted water supply. ${ }^{22}$ 
Traditional village power hierarchies were strongly linked to de-centralised rule and the role of local landlords and other local leaders. Poor security in rural areas meant that farmers and their families were often dependent on landlords and the protection they organised. The physical and mental security offered by landlords and their solid, high walled villages were a great attraction for many poor, rural families and individuals. Alongside the very visible security of the villages themselves, landlords were also able to provide a measure of economic security in the form of seed, maintenance of the irrigation system and other infrastructure, and also by providing loans to farming families to enable them to survive between harvests. The complex system of loans, interest and re-payment that was enacted between landlords (or their agents) and tenants was a very powerful means of ensuring that these tenants remained at the bottom of any hierarchy, and had drastically limited agency in any relationship with the landlord.

It is clear from this that the landlord-tenant system was based on deeply embedded injustices, notwithstanding differences between individual villages, landlords and agents, and was undoubtedly key to the major changes and revolutions of the 20th century, yet it is important to remember that this form of land tenure had endured for more than a thousand years. Lambton and others ${ }^{23}$ have argued that the landlord tenure system has had an almost cyclical quality, whereby different leaders (e.g the Safavids of the 16th `18th centuries) and concomitant different political economies, have led to 'better', more liberal periods, interspersed with periods of hardship and greater insecurity, thus giving landlords both greater power, and also the ability (whether real or not) to offer security in the form of housing, agricultural land, and high walls. This means that in the 20th century, other political, economic and social changes were needed alongside growing discontent among the rural working classes to create a situation where fundamental change was not only desperately needed, it became virtually unstoppable. And in the 20th century, conditions had changed 
through contact with a world that was globalised and industrialised on scales never before achieved, in ways that allowed capitalism through consumerism to penetrate even remote rural villages.

This land tenure system came to an end in the 1960s and 1970s when Reza Muhammad Pahlavi implemented his plan for redistribution of land ownership as part of his White Revolution (a peaceful revolution, as opposed to a violent Red Revolution), and the vast majority of these villages were abandoned in the 1970s or the 1980s, before and after the Islamic Revolution. Political events of the 1950s, and in particular the rise of the communist Tudah or Peoples’ Party, and the power struggles with Prime Minister Mossadeq placed a great deal of pressure on the Shah to enact social and economic change himself, or face reform from below. ${ }^{24}$

While the late 19th and 20th centuries have seen the political economy change dramatically from a feudal or quasi-feudal, despotic, non-capitalist country (or however we might characterise it) to an Islamic Republic or theocracy, it still cannot be understood as a capitalist country. This points to the difficulty of using Western generated economic models in Iran; instead we need to explore and understand it on its own terms. The use of material culture here is both helpful (as it arguably forces us away from these standard models) and difficult (as so little work has been done on material of 19th and 20th centuries, and access to what has been excavated is severely limited).

\section{IRAN'S POLITICAL ECONOMY IN CONTEXT}

The period between the end of the great Safavid dynasty (c.1502-1736) and the start of Qajar rule has been characterised as one with little change in such areas as modes of production, or social hierarchies and the relations between different classes. ${ }^{25}$ The Qajar period (c.1794 to 1925) however, was one of increasingly profound changes particularly from the middle of the 
19th century onwards. These changes laid the foundations for unprecedented political and economic upheaval in the later 20th century, when both the land tenure and dynastic model of control were completely dismantled.

The Qajars were considered weak rulers in many ways, with a reduced army, no direct trade management, reliance on gifting land and villages as rewards for elites and the clergy, as well as greatly enlarging their own (neglected) land holdings, all of which resulted in fragmented agricultural production and social relations, alongside a near total lack of security. ${ }^{26}$ The extensive involvement of Foreign and European powers in the Qajar economy and government, particularly Russia and Britain, has been understood as one of the most significant causes of rapid and fundamental economic, political, and social change. ${ }^{27}$ Rivalry between Russia and Britain in and over Iran is seen by some historians as the big cause of Iran's failure to develop internally during the 19th and 20th centuries, ${ }^{28}$ although other scholars have argued that foreign involvement in fact stimulated growth and opportunity. ${ }^{29}$

Some commentators have described $19^{\text {th }}$-century Iran as feudal or near-feudal and barter was far more common than any kind of monetary system in all but the biggest urban areas. ${ }^{30}$ During the 19th century Iran slowly approached a more modern and Western form of statehood, arguably forced by external contacts rather than internal changes. For example, Iran's wars with Russia showed the urgent need for a modern army, while the mess of the administration and the bankruptcy of government meant that Britain and Russia were able to offer critical financial support followed by political manipulation. ${ }^{31}$ Increasing capitalist activity during the Qajar period was primarily the result of foreign investors, stimulating some local capitalists in the 20th century. ${ }^{32}$ At the same time subsistence agriculture was declining dramatically in favour of cash crops and the power of private landlords was increasing, due to the decayed state of crown land and the gifting of land by the state to powerful individuals. 
From the beginning of the 19th to the middle of the 20th century Iran’s position was critical to British defence of India against France, Russia and Germany. ${ }^{33}$ By the 1830 s Russia was beginning the expansionist moves that led to the 'Great Game', and Iran was a key geographical area for Britain's containment of Russia. ${ }^{34}$ As important as defence was, by the end of the 19th century trade with Iran had taken on huge significance for both Russia and Britain. ${ }^{35}$ Between 1863 and 1914 Iran gave many concessions to the British and Russians, including building telegraphic services across Iran to India, rights to mining, banking, road construction and so forth (some of which were quickly cancelled), and in 1891-92 the British obtained the monopoly over tobacco sales and export which led to the tobacco riots. ${ }^{36}$ Between 1860 and 1913 the British made capital investments of c. $£ 10$ million, mainly in oil and the British bank and other areas benefiting import-exports. ${ }^{37}$ This investment and interest by no means fully benefitted Iran, and in some cases foreign interest actively stifled internal development. For example, in order:

to prevent British goods from reaching northern Iran, the Russians secured an agreement in 1890 from the shah that no railroads would be built in Iran, and virtually none were right up to the 1920 s. $^{38}$

Throughout the Qajar period the import of manufactured and processed products increased in volume and cost, while exports were limited to raw materials of considerably lower value. ${ }^{39}$

Between 1800 and 1914 Russia and European countries as trading partners increased in volume from c. nineteen \% to c. 94\%, accompanied by an increasingly negative balance of trade especially from the mid-19th century onwards. ${ }^{40}$ There was also a major change in the composition of Iran's trade with a severe decline in exports of cotton, wool and silk, which was partly replaced by traditional manufacture such as carpets, and partly by increased export of raw materials such as rice, dried fruits, nuts and opium. In the late 19th century Iran 
exported five times more goods than it imported, yet the imports cost it three times as much. ${ }^{41}$ Trade came not only from Europe and Russia, but from India as well, and when Curzon ${ }^{42}$ visited the bazaars of Mashad (north eastern Iran) in 1890 he reported a lot of Russian goods for sale, alongside Indian trade of tea, minerals, indigo, and a British trade of cottons and cutlery. There was also a major change in the value of trade between Iran and Russia, and Iran and Britain. In 1875 trade with Russia was worth c. $£ 1$ million, and c. $£ 1.7$ million with Britain. By 1914 trade with Russia was c. $£ 12$ million, nearly three times Britain’s c. $£ 4.5$ million. ${ }^{43}$ In 1914 Russia provided 56\% of Iran’s total imports, and took 72\% of Iran’s total exports, while Britain provided 28\% of imports and took thirteen \% of its exports; at this point, Iran was described as part of Russia’s economy. ${ }^{44}$

Since Safavid times (if not earlier), wheat had been the main subsistence crop and in the mid19th century domestic production met all domestic needs, with some wheat and barley even being exported. ${ }^{45}$ A major fall in wheat prices in the second half of the 19th century, alongside a move towards more profitable cash crops changed this situation and by the early 1900s exports of wheat were less than the import of wheat flour. Opium began to rise as a cash crop, particularly in the south, which was of benefit to merchants and landlords, but not to farmers. ${ }^{46}$ The increasing commercialization of agriculture is believed to have played a significant role in the series of famines that occurred during the Qajar period, including the Great Famine of $1869-72$ in which between 500,000 to $1,500,000$ people lost their lives. ${ }^{47}$ The constitutional revolution of 1907 arose from decades of weak rule, foreign interference and resentment of deeply unjust economic structures. It was intended to replace an absolute monarchy with a constitutional monarchy and parliamentary democracy, but resulted in a dictatorial monarchy instead. ${ }^{48}$ The (arguable) success of the Pahlavi regime from 1925 can be understood as a determination to develop central control, of which a strong military (enabled by conscription) was key. ${ }^{49}$ Reza Khan Pahlavi wanted to modernise and Westernise 
his country in ways not always popular (e.g. enforcing male and female dress codes), while at the same time wishing to free Iran from external domination. Such contradictions marked his reign, and in the 1930s his strong links with Germany led to a joint British, American and Russian mission that removed the Shah in 1941, and installed his son Mohammad Reza as Shah. $^{50}$

Ansari $^{51}$ estimates that in 1946 virtually all the wealth and power were invested in one \% of the population who thus had control over the other 99\%. While this power and wealth imbalance was nothing new, events of the first half of the 20th century including greater Western involvement in Iran, the rise of communism in neighbouring Russia, and the spread of an effective means of mass communication in the form of the radio, ${ }^{52}$ changed understandings and ambitions of much of the population. The second part of the 1940s was a period of increasing revolts and separatist movements, accompanied by the rise of the Tudah or Peoples' Party supported by the Soviet Union. ${ }^{53}$ This political movement coincided with a growing dissatisfaction with foreign control of the oil industry, which was increasingly seen as having little or no benefit for the people of Iran. ${ }^{54}$

The Shah launched the White Revolution in 1963 to show that he was taking widespread discontent seriously and making what appeared to be major, radical changes in order to prevent the possibility of a violent revolution. ${ }^{55}$ There were many problems around land reform and redistribution including corrupt, city trained officials taking on some of the most fundamental tasks involved in land recording and redistribution; state schemes that were not properly set up to support mechanization, irrigation, provision of seed, or the credit to enable newly land owning tenants to obtain these critical elements in agricultural production themselves. ${ }^{56}$ The many issues around determining who was entitled to land, and how it was distributed also contributed to the problems and dissatisfaction of both former landlords and tenants. Abrahamian ${ }^{57}$ has calculated that some 1,200,000 former sharecropping families 
ended up owning less than ten hectares each, and as he argues that ten hectares is the minimum needed in many places for adequate subsistence farming, this meant that they found themselves no better off than previously, and often worse off than before land reform.

While land reform did bring about major changes, those who profited most directly from it were those with enough money or power to obtain the most land, whether entitled to it or not. A desperately unjust, unequal social, political and economic system had been torn down; something which most observers and many actors would have welcomed and agreed to be a worthy change. However, as the central political base of the country remained essentially unchanged, and as there was no new realistic and workable framework to take the place of the old landlord tenure system, massive dislocation and dissatisfaction was all too often the short term result. The whole traditional village social system was breaking up in the two decades before the Islamic revolution, leaving a vacuum of dissatisfaction, poverty, and unequal distribution of increasing national wealth. The Shah started to liberalise seriously in 1976, but it quickly became clear that this was simply too little, too late and the growing unrest of the clerics channelled many popular protests into riots from 1978 onwards. ${ }^{58}$ The last Shah of Iran left the country on January 16, 1979; Imam Khomeini arrived back from exile in France on January 31 and by November 1979 Ayatollah Khomeini was head of a theocracy.

\section{THE HISTORICAL ARCHAEOLOGY PROJECT}

The 'landlord villages of the Tehran Plains' project explored three landlord villages between 2007 and 2009, using a combination of building planning and analysis, ethnographic interview and excavation. ${ }^{59}$ We interviewed fourteen people, nine men and five women who had lived in the villages or been associated with them, including the son of a former landlord. Project aims included using material culture to explore the villages and lie within them, 
consider this in light of historical and ethnographic accounts, and to move beyond tenants being presented as an ahistorical, amorphous group of very poor people without agency. This is the view that is presented and reinforced in the accepted histories of rural Iran we draw on to provide background and wider context, and also challenge. In this paper we discuss the village of Kazemabad as our main example, with supporting information from the other villages of Hosseinabad Sangar and Gach Agach when useful. Kazemabad was occupied up until the land reform of the 1970s, and it is not known when it was first established, though we were told during interviews that it had a long history, stretching back hundreds of years; the long lived nature of many locally made goods makes it hard to pin point early occupation archaeologically. ${ }^{60}$ Based on the number of houses in the village described by former occupants, and the average number of people in a family, we estimated the tenant population of Kazemabad as c.150 people, plus the agent and family, and the landlord and his (rarely present) family.

Our work has shown that the village structures themselves were part of the creation and reproduction of hierarchies and inequalities, ${ }^{61}$ and can be understood as microcosms of the Iranian political economy for centuries, whereby massive social and economic inequalities were created and reproduced. Physically, they emphasized and enforced the rules and structures of the society and thus maintained the status, wealth and power of the landlord in a non-capitalist society.

Analyses of the village plans show that in all villages there was a clear separation of the space for the landlord and for the farmers, with the landlord occupying up to half the village (see Fig. 2). As these landlords, and their fathers and grandfathers, were absentees based in Tehran, this reinforces the status and power of those who owned the village, but may have played a very small physical role in everyday life. Landlord's houses were elaborate in terms of interior decoration, number of rooms, and rooms set aside for specific functions, including 
stabling for his sheep, goats, and donkeys. The landlord's area was physically separated from the tenants' part of the village by what would have been a high wall or walls. While preventing the landlord from seeing the tenants and vice versa, the walls would not have cut out the noises or smells from the active village. These walls would have provided a very effective physical and visual barrier, clearly delineating the landlord and tenant space within the village, and been a powerful symbolic reminder of the separation of the two groups.

Tenants' houses were small, simple in plan (see Fig. 2) and plain in terms of interior plaster and niches. Any animals owned by tenants were kept in yards in front of each house. Poorer tenants were lower in the village hierarchy and lived against the external walls, while wealthier villagers lived in houses in the central rows. This status marker can be seen most clearly in the plan of Kazemabad where the houses along the eastern wall have smaller area and rooms than those on the inner row.

One of the most distinctive features of landlord villages was the very high mud brick walls which surrounded and enclosed them (see Fig. 1). These walls were built to a height of some $4 \mathrm{~m}$ with four mud brick towers at each corner representing a significant investment in terms of materials and the labour to build and repair them. The walls and towers would have served a range of aesthetic, practical, symbolic and ideological purposes. They would have provided protection from bandits who terrorised rural settlements; thieves preying on herds; wild animals threatening people, animals and stored grain; and from some extremes of weather. In flat areas like the Tehran Plains the village walls and towers would have been visible from some distance, signalling a place of security and 'home' to residents. They would have also made an immediate statement about the landlord's wealth, status and power to delimit land and people. 
We argue that the buildings and their spatial arrangements acted to legitimise the power of the landlord, and the physical structures were a way of both controlling and ordering the tenants and their families, and of presenting an established order within the villages. ${ }^{62}$ Earlier walls and towers are visible in Kazemabad on the ground and in the plan (see Figs 2 and 3), and these show the longevity of the morphology of villages, and suggest that as a means of reproducing power and inequalities, they worked for a very long time.

\section{EXCAVATED ARTEFACTS AND THE IMPORTS}

The small artefact assemblage from Kazemabad included very little in the way of massproduced items, and only a small number of imported goods (thirteen artefacts, all ceramics. out of a total of 369), which is consistent with a poor community that had minimal participation in the wider cash economy. From our ethnographic interviews with former occupants and people who had been closely associated with the villages through family or trade we learnt that there had been no craft activity such as metalworking or potting in the villages themselves. Pots were bought from nearby local dedicated potting villages, some of which are still in production today, or from the bazaars in nearby towns such as Pishva and Varamin. Metal goods, cloth, shoes, and other non-perishable items were bought from bazaars or from itinerant peddlers who would travel round all villages in an area with a camel or a donkey, selling directly to women at home in the villages during the day. The one exception to this was carpet weaving carried out by women and girls, who sold the finished goods for cash at local markets or to middlemen who then sold the carpets on, often for export to Russia and beyond. ${ }^{63}$ Carpet weaving therefore was the one form of nonagriculturally related economic activity regularly practised in villages, and was an area of craft production that benefited from investment by far-sighted entrepreneurs in the late 19th and early 20th centuries. ${ }^{64}$ 
The location of all trenches at Kazemabad are shown in Fig. 4, intentionally situated to provide a sample of artefacts from locations representing different hierarchies and functions. From all trenches a total of 369 artefacts were recovered, and of these 235 are pot sherds. Of the 235 sherds, 95\% are locally made wares, while the remaining five \% ( $\mathrm{n}=$ thirteen) are what appear to be imported wares with transfer, or decal printed patterns, which all appear to be European in origin (see Fig. 5: 1-4), with one exception. We use the qualifier 'appear' here as these sherds have been identified from photographs only, ${ }^{65}$ as the 2009 Green Revolution prevented both work on the assemblage in Tehran (there are no historical period ceramic experts in Iran) or removal of the assemblage for study outside Iran. These European origin pieces are thought to be from the first half of the 20th century and possibly the end of the 19th century. A single piece is from Russia, and as shown in Fig. 6 this piece was made in the M. Kuznetsov factory between 1892 and $1917 .{ }^{66}$ The M. Kuznetsov factory was located in Verbilki, some 50km north of Moscow, founded by the Englishman Frank Gardner.

The distribution of the thirteen imported pieces is interesting and is summarised in Fig. 7. While the single Russian sherd from the Kuznetsov factory was recovered from an early context in a room in the women's wing of the landlord's house, the remaining pieces were recovered from trenches right across the village. Within the landlords area of the village, one sherd was found in a private room, and six sherds were found in a trench located outside what was identified as the landlord's kitchen, in layers associated with village occupation, and thus likely to represent discarded pieces. One sherd was recovered from trench eight in the agent's house; two sherds from the trench placed at the base of the old wall in the tenant's area, and two sherds from a yard area between tenant houses. This suggests that owning or using imported, manufactured goods was not simply restricted to the landlord's family, and also fits with accounts of increasing imports and consumption of manufactured goods in the early 20th century. 


\section{WHY MIGHT THE PRESENCE OF A VERY SMALL NUMBER OF IMPORTED}

\section{CERAMICS BE IMPORTANT?}

The landlord land tenure system was 'successful' in Iran for a very long time, enduring through centuries of political changes, from possibly as early as the Arab invasions and adoption of Islam. That this system finally failed in the later part of the 20th century suggests that the causes of change must have been more than the internal failings and disputes of the Qajar and Pahlavi dynasties, as Iran has had periods of prosperity, growth, and enlightenment, interspersed with periods of contraction, poverty, and oppression, all closely linked to the political economy over the last 1300-1400 years. There have also been periods of greater and lesser foreign involvement, for example the Safavid period was a time of international trade with a powerful international court, and many foreign powers desired strong links with the Safavid rulers; this was followed by the Asfarid and Zand dynasties, where weak, decentralised rule and rampant rural violence made Iran a highly undesirable place for foreign visitors.

What happened in the 19th and 20th centuries that led to such sweeping and major change evidenced in this case study by the removal of this long-lived landlord system? Thirteen pieces of imported ceramics (twelve from Europe and one from Russia) dated from the late 19th to mid-20th century perhaps provide part of the answer. These sherds stand out in a small artefact assemblage largely limited to locally made goods, mostly linked to agriculture or food preparation and consumption. Without the thirteen sherds we have an assemblage that is indicative of a very poor, very insular community with little hierarchical distinction. The material poverty of the villages is clear, as is their longevity. This appearance of foreign imports in the form of ceramics is therefore a highly significant change, and arguably indicative of the transformative power of the wider political and economic changes that led to the White and Islamic Revolutions of the later 20th century. 
The later 19th and early 20th century date range estimates for the Russian and European ceramics, from a site occupied from at least the earlier 19th century (according to our interviewees) up to the 1970s, coincide with the period during which British and Russian imports increased greatly, and also the period during which agricultural change and the expansion of cash crops were both causing major famines and poverty, and also slowly enmeshing rural communities into a broader cash economy across Iran, albeit with little demonstrable benefit to share croppers and the wider rural population. Surely it is critical that during a period of major, almost entirely negative changes to farmers we see the appearance of imported ceramics in this poor, remote village. That no imported ceramics were recovered from the mid-late 20th century is also interesting, as this could be viewed as the impact of the political changes taking place right across Iran during the rule of the last Shah, as well as the ongoing attempts of the Pahlavis to move away from foreign control, in voice if not in actuality.

The single Russian sherd was found in the women's room of landlord's house, and this strongly indicates that this was a valuable piece belonging to the wealthy landlord's family. Coming from a well-known, prestigious manufacturer, this piece is likely to have been brought from Tehran by the women of the landlord's family during one of their infrequent visits to the village. We know from our ethnographic interviews that the landlord of Kazemabad and his family lived in Tehran, and while the landlord used the village as a weekend hunting lodge, the women of his family only rarely came with him. There was also agreement that this had been the situation in previous generations as well, although this is obviously rather more speculative. We were also told that the landlord would select women from the village to help the agent's wife look after his house, and this might well include the practice of temporary marriages ${ }^{67}$ between the landlord and women of the village. These fluid roles for women may be important in explaining the presence of imported European 
sherds right across the village. ${ }^{68}$ They may have been brought to the village initially by the landlord or his wife, and then given to individual village women as gifts or when no longer considered useful or desirable by the landlord and his family, or they may have been borrowed or stolen by them. The ceramics may possibly have been acquired when already broken and taken by the village women as mementos or colourful items. The pieces might have been bought by village women themselves in local bazaars or in Tehran, whether they were imitating ceramics seen in the landlord's house, or prompted by the desire to own pieces seen for themselves in the towns and cities. Women did participate in the burgeoning cash economy through their production of carpets, ${ }^{69}$ and they made decisions about purchases for the household, including buying kitchen and table wares whether from bazaars or from itinerant merchants. While the amount of money that women made from carpets was limited, and would often have been of critical value in supporting families, this does indicate that women had a degree of purchasing power, no matter how small. It is also possible that the village women taking care of the landlord's house bought his tableware on his behalf, and were able to choose more expensive pieces for his house than they would for his own; possibly even with a long term aim of cycling such pieces to their own houses over time. Whatever route or combination of routes was involved we can be confident that women were involved in procuring the ceramics found in the village, and that by some means these imported pieces were owned or shared beyond the landlord's house.

Whether brought directly to the village by the landlord or the women of his family, or bought by the village women themselves, the ideas and possibilities that are inherent in exotic goods would have changed thinking and understandings of the wider world forever, even if only very subtly. If these ceramics had been purchased by village women then they have the power to tell us about their poverty and agency, and suggest different understandings of women's roles than generally presented in historic and ethnographic accounts. What they do 
tell us is that the capitalism, consumerism, and global trade known from histories of Iran in the 19th and 20th centuries had penetrated even the poorest of these remote landlord villages. The durability of ceramics is of course well known, and it is surely reasonable to suggest that alongside these non-organic artefacts, imported organic items may also have been present, such as textiles.

\section{CONCLUSION}

The longevity of the landlord village system in Iran is well known from historical analyses, controlling social and economic structures and relations for centuries. This inherently unjust and unequal relationship has been embodied in the physical village, with the use of walls, space delimitation, control of movement and so forth to express and reinforce hierarchy and control. ${ }^{70}$ The endurance of the landlord village system of land tenure through time and through many different dynasties, each with different approaches to leadership and engagement with the world beyond Iran itself shows how powerful this social and economic structure was. That it was finally and permanently dismantled in the latter part of the 20th century shows that major political and economic changes had taken place, of a magnitude and depth never before comprehended. While the increasing involvement of Russia and Britain in Iran is well attested historically, what is shown by this exploration of imported ceramics in a landlord village is that global capitalism and consumerism was penetrating the poorest and remotest segments of rural Iranian society and in doing so, was changing these people and places permanently. The wider, international changes provided the spaces, or triggers needed for change on a scale and in ways that had never before been encountered. The Shah, the government, and the elites all found benefits in engagement with capitalism and trade in the short and medium terms, and that part of this engagement trickled down to the rural poor in the form imported goods indicates the reach of consumption of imported goods. While this consumption alone did not lead to the dismantling of the landlord tenure system, it was part 
of the bigger political and economic systems that were changing much of the world in the post medieval period. That official records show the dominance of Russia from the last quarter of the 19th century onwards, with Britain playing a lesser role in trade is not reflected in the (admittedly very tiny) sample from Kazemabad. Here, the Russian sherd is obviously an important piece, but in numerical terms the European pieces are far more significant, and that they also come from countries that are far smaller players than Britain and Russia in Iranian trade terms raises a lot of interesting questions about the types of consumerism and the types of goods that were influencing rural communities. In order to fully explore and address these and other questions around the material culture of the political economy of the Qajar and Pahlavi periods, more historical archaeology work is needed to obtain comparable samples. And finally, despite engagement with Western nations and Western capitalism for nearly 200 years now, and the impact this engagement has had on one of the most fundamental economic and social structures of Iranian society for many centuries, Iran is not a capitalist country or economy, in the way that we would identify Britain, or the USA, or even India as a capitalist economy today.

\section{NOTES}

${ }^{1}$ Dandamaev and Lukonin 1989; Lambton 1953.

${ }^{2}$ Bausani, 1962; Lambton, 1953.

${ }^{3}$ Hooglund 1982.

${ }^{4}$ Keddie 1980, 140; Lambton 1953.

${ }^{5}$ Bausani 1962; Lambton 1953.

${ }^{6}$ Kurzman 2004, 96; Lambton, 1953, 266. 
${ }^{7}$ Hooglund, 1982, 10.

${ }^{8}$ Richards 1975, 4.

${ }^{9}$ Richards 1975, 4.

${ }^{10}$ Lambton 1953, 263.

${ }^{11}$ Keddie 1966, 75.

12 Katouzian 1981, 20-1; Richards 1975.

${ }^{13}$ Foran 1989, 40-2.

${ }^{14}$ Nezam-Mafi 1993, 5; Richards 1975, 4.

${ }^{15}$ Nezam-Mafi 1993, 7.

${ }^{16}$ Lambton 1953, 152.

${ }^{17}$ Hooglund 1982, 25.

${ }^{18}$ English, 1966; Hooglund, 1982; Keddie, 1980.

${ }^{19}$ Curzon 1892, 490; Keddie 1980, 172-3, 201.

${ }^{20}$ Bausani, 1962, 19; Lambton, 1953, 90, 99.

${ }^{21}$ Keddie 1968, 69.

22 Nezam-Mafi 1993, 10.

${ }^{23}$ Bausani 1962; Dandamaev and Lukonin 1989; Lambton 1953.

${ }^{24}$ Ansari 2003, 150.

${ }^{25}$ Andic 2012, 609; Foran 1989, 50. 
${ }^{26}$ Foran 1989, 53-4.

${ }^{27}$ e.g. Ansari 2003; Katouzian 1981; Mahdavi 2013.

${ }^{28}$ Andic 2012, 599; Ansari 2003, 9; Foran 1989, 9; Seyf 2004.

${ }^{29}$ Gilbar 1986, 77; see Foran 1989.

${ }^{30}$ Mathee 2013, 334; Richards 1975, 4.

${ }^{31}$ Arbuthnott 2008, 16.

${ }^{32}$ Foran 1989, 52.

${ }^{33}$ Arbuthnott 2008, 4.

${ }^{34}$ Foran 1989, 10; Katouzian 1981, 59.

${ }^{35}$ Arbuthnott 2008, 57.

${ }^{36}$ Foran 1989, 11; Keddie 1966.

${ }^{37}$ Foran 1989, 12.

${ }^{38}$ Foran 1989, 13.

${ }^{39}$ Foran 1989, 13; Seyf 2004, 59-65.

${ }^{40}$ Foran 1989, 16,18.

${ }^{41}$ Foran 1989, 21.

${ }^{42}$ Curzon 1892.

${ }^{43}$ Foran 1989, 14, table 1.

${ }^{44}$ Foran 1989, 14. 
${ }^{45}$ Foran 1989, 25.

${ }^{46}$ Foran 1989, 26; Keddie 1966.

${ }^{47}$ Foran 1989, 24.

${ }^{48}$ Abghari 2007, 247.

${ }^{49}$ Ansari 2003, 17, 22.

${ }^{50}$ Ansari 2003, 73.

${ }^{51}$ Ansari 2003, 77.

${ }^{52}$ Hegland 2014, 152; Anderson 2006.

53 Ansari 2003, 77.

${ }^{54}$ Arbuthnott 2008, 36-7.

${ }^{55}$ Arbuthnott 2008, 43.

${ }^{56}$ Ansari 2003, 158; Hooglund 1982.

${ }^{57}$ Abrahamian 2008, 132.

${ }^{58}$ Arbuthnott 2008, 45.

${ }^{59}$ Fazeli and Young 2013; Fazeli et al 2009; Fazeli and Young 2008.

${ }^{60}$ Fazeli and Young 2013; Fazeli et al 2009; Fazeli and Young 2008.

${ }^{61}$ Fazeli and Young 2013.

${ }^{62}$ Fazeli and Young 2013.

${ }^{63}$ Young and Fazeli 2013. 
${ }^{64}$ Gilbar 1986, 83.

${ }^{65}$ Alasdair Brooks pers. comm.; Sarah Newstead pers.comm.

${ }^{66}$ Russian Antique 2006.

67 ‘Abd al ‘Afi 1977, 103; Foran 1989, 31.

${ }^{68}$ Young \& Fazeli 2013.

${ }^{69}$ Young and Fazeli 2013.

${ }^{70}$ Fazeli and Young 2013.

\section{ACKNOWLEDGEMENTS}

This project has been funded by the British Institute of Persian Studies. The authors would like to thank the following institutions and individuals: Iran Centre for Archaeological Research; University of Tehran; University of Leicester; Azad University, Varamin-Pishva; Iran National Museum; National Centre for Handicrafts and Heritage, Iran; American University of Beirut. Mr Pooria Saeedi (draughtsman), Ms Hengameh Ilkani (ethnographer and translator), Ms Minoo Salimi (ethnographer and archaeologist), Ms Maryam Naimi (ethnographer, translator and archaeologist), Ms Nastaran Moradi, Mr Amir Arab, Mr Abolfazl Moheban, Mr Hassan Asghari, Mr Sajjad Arabsharab, Mr Mohammad Sadeghi, (all archaeologists); Mr Suleymanye (driver), Mr Ali Abargarhoui, Mr Haj Ahmed Akbari, Mr Haj Abolgasm Ghodsi, Mr Hassan Hosseini, Mr Khale Khoui, Mr Haj Akbar Mahabadi, Mrs 
Kouchak, Ms Jamileh Emem Ghouli and the Kazempour family, Mr Mohummad Hossein Mohseni, Mr Hassan Rahimi, Mr Mohsen Arab Salmani, Mr Abas Ramazon Zadeh, Mr Haj Mahmoudh Zaraei, Mr Faraj Uriyat, Mr Aziz Uriyat, Mr Mahmod Sahriai, Mrs Zahra Jamali, and Mr Jafari; Professor Graeme Barker, University of Cambridge; Professor Audrey Horning, Queen’s University Belfast; Professor Timothy Insoll, University of Exeter; Professor Roger Matthews, University of Reading; Dr Wendy Matthews, University of Reading; Dr Paul Newson, American University of Beirut. We are also very grateful to the Centre for Historical Archaeology in the School of Archaeology and Ancient History, University of Leicester and the inspiration and help provided by members.

The site archive is held in the School of Archaeology and Ancient History, University of Leicester, UK; the finds are held in the Department of Archaeology, Tehran University, Iran. 


\section{BIBLIOGRAPHY}

'Abd al 'Afi, H. 1977, The Family Structure in Islam, Indianapolis: American Trust Publications.

Abghari, S. 2007, 'Political economy of political power of the Islamic regime in Iran', J. of Third World Studies 24:1, 247-59.

Abrahamian, E. 2008, A History of Modern Iran, Cambridge: Cambridge University Press. Andic, S. 2012, 'When Garibaldi went to Azerbaijan: A Study of British Perceptions of the Iranian Constitutional Revolution, Part 1, 1906-07’, Iranian Studies 45:5, 597-618.

Anderson, B. 2006, Imagined Communities. Reflections on the Origin and Spread of Nationalism, London, Verso.

Ansari, A.M. 2003, Modern Iran Since 1921. The Pahlavis and After, London: Longman. Arbuthnott, H. 2008, 'Iran’, in Arbuthnott, Muir and Clark 2008, 3-77.

Arbuthnott, H., Muir, R. \& Clark, T. (eds) 2008, British Missions Around the gulf, 15752005: Iran, Iraq, Kuwait, Oman, Ebsco Publishing: Global Oriental.

Bausani, A. 1962, The Persians from the earliest days to the twentieth century, London: Elek books.

Curzon, G.N. 1892, Persia and the Persian Question, London: Longmans, Green and Co. Dandamaev, M.A. \& Lukonin, V.G. 1989, The culture and social institutions of ancient Iran, Cambridge University Press, Cambridge.

English, P.W. 1966, City and Village in Iran: settlement and economy in the Kirman Basin, Madison, Wisconsin: University of Wisconsin Press.

Fazeli, H. \& Young, R. 2013, ‘Landlord villages of Iran as landscapes of hierarchy and control', International J. of Hist. Archaeo. 17:1,143-58.

Fazeli,H., Salimi, M. \& Young, R. 2009, ‘Landlord Villages of the Tehran Plain, and Historical Archaeology in Iran’, Iran XLVII: 149-64. 
Fazeli, H. \& Young, R. 2008, 'Landlord Villages of the Tehran Plain: season 1', Iran XLVI: $347-60$.

Foran, J. 1989, 'The Concept of Dependent Development as a Key to the Political Economy of Qajar Iran (1800-1925)', Iranian Studies 22:2/3, 5-56.

Gilbar, G.G. 1986, 'The Opening Up of Qajar Iran: Some Economic and Social Aspects’ Bulletin of the School of Oriental and African Studies 49:1, 76-89.

Hegland, M.E. 2014, Days of Revolution. Political Unrest in an Iranian Village, Stanford, California: Stanford University Press

Hooglund, E.J. 1982, Land and Revolution in Iran, 1960-1980, Austin: University of Texas Press.

Katouzian, H. 1981, The Political Economy of Modern Iran. Despotism and PseudoModernism, 1926-1979, London: MacMillan Press.

Keddie, N.R. 1980, Iran. Religion, Politics and Society, London: Frank Cass and Company. Keddie, N.R. 1966, Religion and Rebellion in Iran. The Tobacco Protest of 1891-1892, London: Frank Cass \& Co. Ltd.

Kurzman, C. 2004, The Unthinkable Revolution in Iran, Cambridge, Massachusetts: Harvard University Press.

Lambton, A.K.S. 1953, Landlord and peasant in Persia: A study of land tenure and land revenue administration, Oxford: Oxford University Press.

Mahdavi, S. 2013, ‘Irano-Russian trade and Travel: Haj Muhammad Hassan Amin al-Zarb and Others', Iranian Studies 46:2, 207-26.

Matthee, R. 2013, ‘The Political Economy of Iran under the Qajars: Society, Politics, Economics and Foreign Relations 1796-1926 by Hooshan Amirahmadi (review)', The Middle East J. 67:2, 333-35. 
Nezam-Mafi, M.E. 1993, ‘The Khālisah of Varamin', International J. of Middle East Studies 25:1, 5-15.

Richards, H. 1975, 'Land Reform and Agribusiness in Iran’, MERIP Reports, 1 December 1975, 43, 3-24.

Russian Antique, 2006, Ceramics and ceramic stamps,

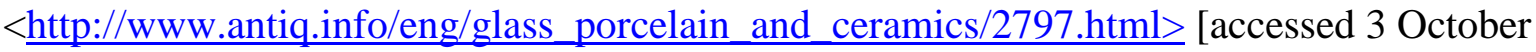
2008].

Seyf, A. 2004, 'Free Trade, Competition, and Industrial Decline: The Case of Iran in the Nineteenth Century’, Middle Eastern Studies, 40:3, 55-74.

Young, R. \& Fazeli, H. 2013, 'Women and Class in Landlord Villages of the Tehran Plain, Iran’, Hist. Archaeo. 47:2, 77-99. 